\title{
PERAN KELUARGA DALAM PENDIDIKAN ANAK: Studi Ayat 13-19 Surat Luqman
}

\author{
Lutfiyah \\ Universitas Islam Negeri (UIN) Walisongo Semarang \\ e-mail: lutfiyahmsi@yahoo.co.id
}

\begin{abstract}
Abstrak
Keluarga merupakan masyarakat terkecil yang berpotensi membentuk masyarakat Islami. Dengan pendidikan yang benar anak akan terbebas dari dekadensi moral. Dalam Surah Luqman ayat 13-19 seorang ayah yang bijak memberikan wasiat kepada anaknya untuk mengamalkan ketauhidan tanpa menyekutukan Allah, berbakti kepada orang tua terutama ibu yang telah mengandung dan melahirkan, beriman dengan memercayai keberadaan Allah dan tetap memujinya, berakhlaq yang baik terhadap sesama. Empat hal tersebut bila dirangkum menjadi 3 pilar wasiat yaitu pelajaran aqidah, syariah dan akhlaq. Wasiat Luqman bukan wasiat tanpa teladan, tetapi terlebih dahulu ada teladan dari orang tua. Teladan merupakan benang merah yang tidak boleh diputus karena tanpa meneladani wasiat tersebut menurunkan kepercayaan anak terhadap orang tua.
\end{abstract}

Kata Kunci: keluarga; Luqman; wasiat

\section{A. Pendahuluan}

Dari berita TV, sosial media dan surat kabar sering kita melihat, mendengar dan membaca kasus kekerasan terhadap anak, kenakalan anak atau kenakalan remaja. Ada yang menghujat ada yang diam ada yang bertanya. Yang menghujat menganggap bahwa lingkungan sudah tidak bersahabat terhadap anak yang menyebabkan anak menjadi tidak terlindungi, yang diam mungkin serba salah untuk mengungkapkan argumen dan yang bertanya mungkin ingin mencari solusi kenapa ada kekerasan terhadap anak, kenakalan anak atau kenakalan remaja yang semakin hari semakin menyedihkan.

Ada benang yang tidak boleh diputus bahwa anak lahir dan berasal dari keluarga. Bayi, anak-anak, remaja, dewasa, menjadi orang tua, berkeluarga mempunyai bayi, mempunyai anak remaja, mempunyai anak dewasa dan seterusnya adalah siklus yang tidak bisa diputus. Di sinilah akan 
dibahas dari mana kekerasan itu berasal meskipun lingkungan juga punya pengaruh yang tidak kalah serius.

Mendidik anak merupakan kewajiban orang tua dan utama mengingat keluarga merupakan lingkungan pendidikan pertama dimana anak akan berinteraksi dengan keluarga. norma dan aturan yang ditanamkan dalam keluarga akan melebur dalam diri anak sehingga perilakunya di luar merupakan cermin dari perilakunya dalam keluarga, meskipun dalam beberapa kasus terjadi pengecualian.

Allah mempertegas fungsi keluarga dalam mendidik anak dalam Surah al-Tahrim ayat 6:

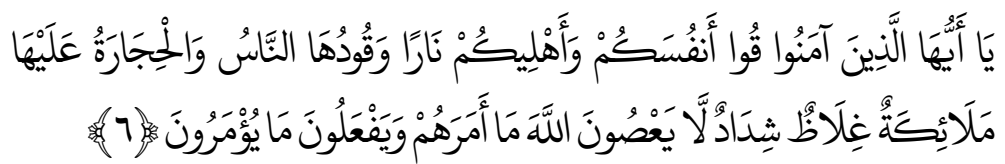

"Hai orang-orang yang beriman, peliharalah dirimu dan keluargamu dari api neraka yang bahan bakarnya adalah manusia dan batu; penjaganya malaikat-malaikat yang kasar, keras, dan tidak mendurhakai Allah terhadap apa yang diperintahkan-Nya kepada mereka dan selalu mengerjakan apa yang diperintahkan".

Ayat di atas dapat dipahami bahwa posisi keluarga mempunyai tanggung jawab yang sangat besar bagi perkembangan anak sehingga anak akan selamat dari jilatan api neraka. Maka dasar utama yang diletakkan adalah dasar-dasar tingkah laku dan budi pekerti (akhlak) anak didik.

Dalam kenyataan sehari-hari tidak jarang kita temui pihak orang tua (lingkungan keluarga) yang gagal atau kurang berhasil dalam membina, mengarahkan serta mendidik anak-anaknya sebagai anak yang baik dan berakhlak shaleh.

Islam sangat memperhatikan hak anak. Pertama hak anak untuk memperoleh orang tua yang shaleh. Jauh-jauh al-Qur'an sudah mengultimatum dalam Surah al-Baqarah ayat 221 bahwa jangan menikah dengan wanitawanita musyrik, sebelum mereka beriman. Sesungguhnya wanita budak yang mukmin lebih baik dari wanita musyrik, walaupun dia menarik hati. Dan jangan kamu menikahkan orang-orang musyrik (dengan wanitawanita mukmin) sebelum mereka beriman. Sesungguhnya budak yang mukmin lebih baik dari orang musyrik walaupun menarik hati. 


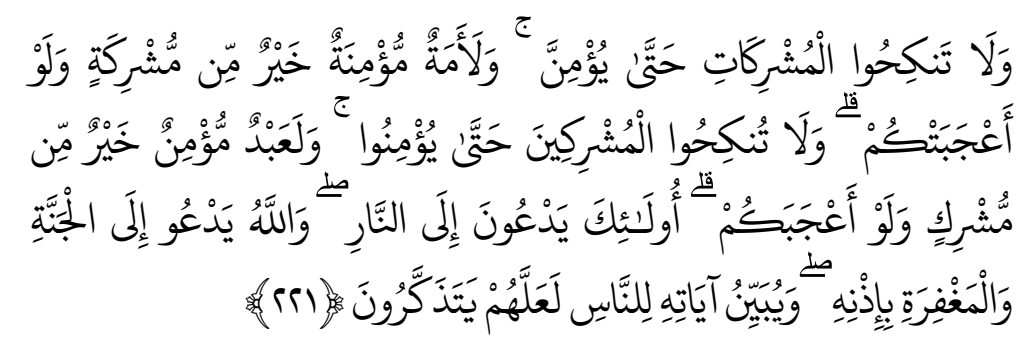

"Dan janganlah kamu nikahi wanita-wanita musyrik, sebelum mereka beriman. Sesungguhnya wanita budak yang mu'min lebih baik dari wanita musyrik, walaupun dia menarik hatimu. Dan janganlah kamu menikahkan orang-orang musyrik (dengan wanitawanita mu'min) sebelum mereka beriman. Sesungguhnya budak yang mu'min lebih baik dari orang musyrik walaupun dia menarik hatimu. Mereka mengajak ke neraka, sedang Allah mengajak ke surga dan ampunan dengan izin-Nya. Dan Allah menerangkan ayatayat-Nya (perintah-perintah-Nya) kepada manusia supaya mereka mengambil pelajaran."

Kedua, hak untuk hidup. Secara umum Allah melarang menghilangkan nyawa seseorang sebagaimana yang telah difirmankan dalam Surah alMaidah ayat 32 bahwa barang siapa yang membunuh seorang manusia, bukan karena orang itu (membunuh) orang lain, atau bukan karena membuat kerusakan di muka bumi, maka seakan-akan dia telah membunuh manusia seluruhnya. Dan barang siapa yang memelihara kehidupan seorang manusia, maka seolah-olah dia telah memelihara kehidupan manusia semuanya. Lebih khususnya lagi pada Surah al-An'am ayat 151 bahwa janganlah kamu membunuh anakmu kerena takut miskin.

Ketiga hak anak dalam pemberian nama yang baik. Memberi nama hendaklah nama yang baik yang mengandung arti. Sejak dulu setiap ada kelahiran anak maka anak itu akan diberi nama sebagaimana yang dilakukan oleh istri Imron dalam Surah Ali Imran ayat 36 bahwa sesungguhnya Istri Imran telah menamai anaknya dengan nama Maryam dan istri Imran mohon perlindungan untuknya serta anak-anak keturunannya kepada (pemeliharaan) Allah dari setan yang terkutuk. Maryam merupakan nama yang baik yang artinya wanita yang gemar beribadah. Melihat tiga hal di atas maka bisa diambil kesimpulan seentara bahwa anak adalah tanggung jawab orang tua dan berhak mendapatkan yang terbaik untuk dirinya termasuk sebelum anak itu lahir. 


\section{B. Pengertian Pendidikan}

Secara etimologis pendidikan berasal dari bahasa Yunani "paedagogike. Kata ini merupakan kata gabungan dari "pais" yang berarti "anak" dan kata "ago" yang berarti "aku membimbing". Maka paedagogike berarti aku membimbing anak. Orang yang pekerjaan membimbing anak dengan maksud membawanya ke tempat belajar, dalam bahasa Yunani disebut "paedagogos". ${ }^{1}$ maka pendidikan adalah usaha untuk membimbing anak.

Dalam konsep pendidikan Islam, hakikat pendidikan adalah usaha orang dewasa muslim yang bertaqwa secara sadar mengarahkan dan memebimbing pertumbuhan serta perkembangan fitrah (kemampuan dasar) anak didik melalui ajaran Islam kearah titik maksimal pertumbuhan dan perkembangannya. ${ }^{2}$ Nabi pernah bersabda bahwa setiap anak dilahirkan dalam keadaan fitrah maka orang tualah yang menjadikannya Yahudi, Nasrani dan Majusi. Fitrah dalam hadis tersebut mengandung makna potensi (kemampuan dasar anak). Para mufassirin menyebutkan bahwa fitrah diartikan sebagai potensi kebaikan yang dibawa anak sejak lahir.

Menurut Burhanudin istilah fitrah dapat dipandang dari dua sisi, yaitu sisi bahasa dan agama. Dari sisi bahasa makna fitrah adalah suatu kecenderungan bawaan alamiyah manusia. Sementara dari sisi agama fitrah mengandung makna keyakinan agama, yaitu manusia sejak lahir telah memiliki fitrah agama tauhid mengesakan Tuhan. ${ }^{3}$

Pendidikan merupakan suatu proses yang berlangsung dalam kehidupan sebagai upaya untuk menyeimbangkan kondisi dalam diri dengan kondisi luar diri. Proses penyeimbangan ini merupakan bentuk survive yang dilakukan agar diri dapat mengikuti setiap kegiatan yang berlangsung dalam kehidupan.

\section{Pesan Luqman Hakim dalam al-Qur'an}

Luqman merupakan sebuah nama yang diabadikan dalam salah satu Surah yang ada dalam al-Qur'an. Ada kontroversi terhadap diri Luqman

\footnotetext{
${ }^{1}$ A. Hadi Soedomo, Pendidikan: Suatu Pengantar, (Surakarta: UNS Press, 2008), h. 17.

${ }^{2}$ Mansur, Pendidikan Anak Usia Dini dalam Islam, (Yogyakarta: Pustaka Pelajar, 2009), h. 84.

3Burhanudin, Paradigma Psikologi Islam, Studi tentang Elemen Psikologi dari al-Qur'an, (Yogyakarta: Pustaka Pelajar, 2004), h. 148.
} 
tentang siapa dia hingga layak diceritakan kisahnya dalam al-Qur'an dan nasihatnya menjadi rujukan banyak penelitian tentang bagaimana layaknya menjadi orang tua yang baik yang bisa menasihati anaknya.

Dalam Tafsir Shawy ${ }^{4}$ disebutkan bahwa Luqman adalah Luqman bin Faghur bin Nakhur nin Tarakh yang disebut juga dengan Azar. Ada yang mengatakan bahwa Luqman adalah anak saudara perempuan nabi Ayub, ada yang mengatakan Luqman adalah anak dari bibi nabi Ayub. Ada yang mengatakan bahwa dia hidup seribu tahun sehingga bisa bertemu dengan nabi Dawud. Ada satu kesepakatan bahwa Luqman bukan seorang nabi tapi seorang bijak kecuali pendapat Ikrimah dan al-Syukbi yang berpendapat bahwa Luqman adalah seorang nabi.

Perselisihan lain terkait diri Luqman adalah asal kotanya. Ada yang mengatakan dari Nuba (Namibia) dari penduduk Ailah, ada juga yang menyebutkan dari Etiopia. Pendapat lain mengatakan bahwa ia dari Mesir Selatan yang berkulit hitam. Ada lagi yang mengatakan dia seorang Ibrani. Profesinya juga diperselisihkan, ada yang mengatakan dia seorang penjahit, pekerja pengumpul kayu atau tukang kayu, ada juga yang mengatakan pengembala. ${ }^{5}$

Pesan yang termaktub dalam al-Qur'an adalah sebagai berikut:

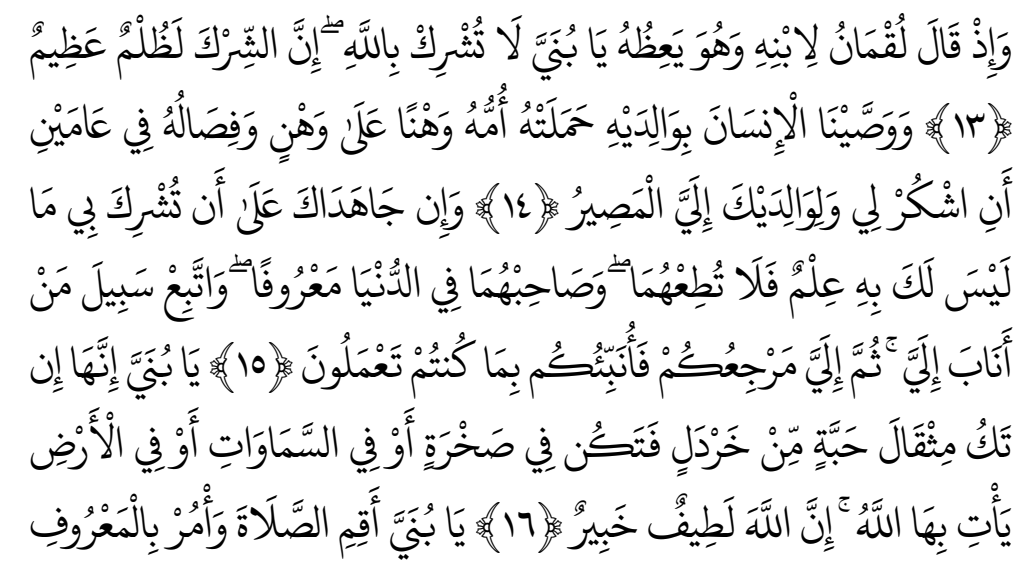

4al-Malikiy, Hasyiyah al-Allamah Shawiy ala Tafsir al-Jalalain, (Beirut: Dar al-Fikr, 1993), Jilid 3, h. 313.

${ }^{5}$ M. Quraish Shihab, Tafsir al-Misbah: Pesan, Kesan dan Keserasian al-Qur'an, Vol. 10, (Jakarta: Lentera Hati, 2009), h. 297. 


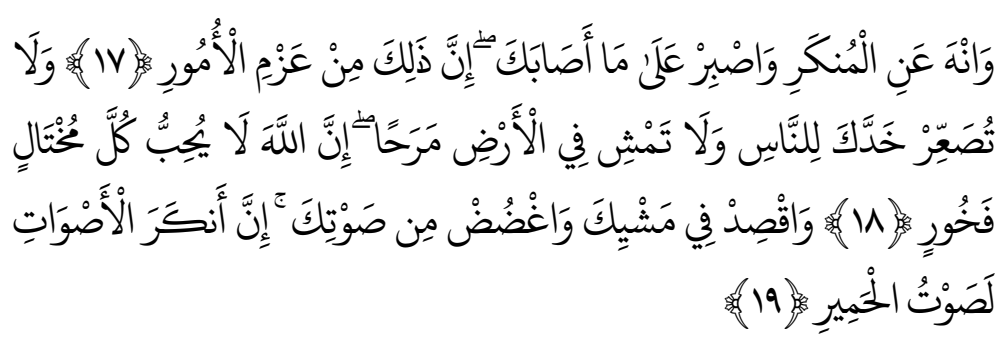

13. dan (ingatlah) ketika Luqman berkata kepada anaknya, di waktu ia memberi pelajaran kepadanya: "Hai anakku, janganlah kamu mempersekutukan Allah, Sesungguhnya mempersekutukan (Allah) adalah benar-benar kezaliman yang besar".

14. dan Kami perintahkan kepada manusia (berbuat baik) kepada dua orang ibu- bapanya; ibunya telah mengandungnya dalam Keadaan lemah yang bertambah-tambah, dan menyapihnya dalam dua tahun. bersyukurlah kepadaku dan kepada dua orang ibu bapakmu, hanya kepada-Kulah kembalimu.

15. dan jika keduanya memaksamu untuk mempersekutukan dengan aku sesuatu yang tidak ada pengetahuanmu tentang itu, Maka janganlah kamu mengikuti keduanya, dan pergaulilah keduanya di dunia dengan baik, dan ikutilah jalan orang yang kembali kepada-Ku, kemudian hanya kepada-Kulah kembalimu, maka Kuberitakan kepadamu apa yang telah kamu kerjakan.

16. (Luqman berkata): "Hai anakku, Sesungguhnya jika ada (sesuatu perbuatan) seberat biji sawi, dan berada dalam batu atau di langit atau di dalam bumi, niscaya Allah akan mendatangkannya (membalasinya). Sesungguhnya Allah Maha Halus lagi Maha mengetahui.

17. Hai anakku, dirikanlah shalat dan suruhlah (manusia) mengerjakan yang baik dan cegahlah (mereka) dari perbuatan yang mungkar dan bersabarlah terhadap apa yang menimpa kamu. Sesungguhnya yang demikian itu Termasuk hal-hal yang diwajibkan (oleh Allah).

18. dan janganlah kamu memalingkan mukamu dari manusia (karena sombong) dan janganlah kamu berjalan di muka bumi dengan angkuh. Sesungguhnya Allah tidak menyukai orang-orang yang sombong lagi membanggakan diri.

19. dan sederhanalah kamu dalam berjalan dan lunakkanlah suaramu. Sesungguhnya seburuk-buruk suara ialah suara keledai. 
Sebab turunnya ayat 13-19 dari Surah Luqman tidak ditemukan adanya sebab yang melatarbelakangi turunnya ayat tersebut, hanya saja dalam ayat 13 dalam Tafsir al-Misbah, diriwayatkan bahwa Suwayd ibn ash-Shamit suatu ketika datang ke Makah. Ia adalah seorang yang cukup terhormat di kalangan masyarakatnya. Lalu Rasulullah mengajaknya untuk memeluk agama Islam. Suwayd berkata kepada Rasulullah, "Mungkin apa yang ada padamu itu sama dengan yang ada padaku." Rasulullah berkata, "Apa yang ada padamu?" Ia menjawab, "Kumpulan hikmah Lukman." Kemudian Rasulullah berkata, "Sungguh perkataan yang amat baik! Tetapi apa yang ada padaku lebih baik dari itu. Itulah al-Qur'an yang diturunkan Allah kepadaku untuk menjadi petunjuk dan cahaya." Rasulullah lalu membacakan al-Qur'an kepadanya dan mengajaknya memeluk Islam. ${ }^{6}$

Diriwayatkan bahwa ayat 15 ini diturunkan berhubungan dengan Sa'ad bin Abi Waqqas, ia berkata, "Tatkala aku masuk Islam, ibuku bersumpah bahwa beliau tidak akan makan dan minum sebelum aku meninggalkan agama Islam itu. Untuk itu pada hari pertama aku mohon agar beliau mau makan dan minum, tetapi beliau menolaknya dan tetap bertahan pada pendiriannya. Pada hari kedua, aku juga mohon agar beliau mau makan dan minum, tetapi beliau masih tetap pada pendiriannya. Pada hari ketiga, aku mohon kepada beliau agar mau makan dan minum, tetapi tetap menolaknya. Oleh karena itu, aku berkata kepadanya, Demi Allah, seandainya ibu mempunyai seratus jiwa dan keluar satu persatu di hadapan saya sampai ibu mati, aku tidak akan meninggalkan agama yang aku peluk ini. Setelah ibuku melihat keyakinan dan kekuatan pendirianku, maka beliaupun mau makan."7

Diriwayatkan pula bahwa Asma' putri Abu Bakar pernah didatangi oleh ibunya. Waktu itu ibunya masih musyrikah. Asma' berkata kepada Nabi bagaimana dia bersikap. Maka Rasulullah memerintahkannya untuk tetap menjalin hubungan baik, menerima dan memberinya hadiah serta mengunjungi dan menyambut kunjungannya. ${ }^{8}$

${ }^{6}$ M. Quraish Shihab, Tafsir al-Misbah, h. 296.

${ }^{7}$ Muhammad Ahsin Sakho, et.,all., al-Qur'an dan Tafsirnya, (Jakarta: Lentera Abadi, 2010,), h. 553.

${ }^{8}$ M. Quraish Shihab, Tafsir al-Misbah, h. 304. 


\section{Pendidikan Anak: antara Normatif dan Aplikatif}

Memahami ayat al-Qur'an bisa diawali dengan memahami terjemah harfiyahnya mengingat al-Qur'an bukan bahasa orang Indonesia. Dari terjemah tersebut akan timbul banyak pertanyaan tentang untuk apa sebuah ayat diturunkan, apa ada pertanyaan, apa ada sebuah peristiwa atau ayat tersebut adalah sebuah kisah mauidhah yang bisa diambil pelajaran bagi umat yang menganggap al-Qur'an sebagai petunjuk bagi kehidupan manusia.

Metode pendidikan yang termaktub dalam Surah tersebut menunjukkan metode yang bisa dijadikan pedoman oleh orang tua, yaitu:

a. Metode mauizah (nasihat), metode ini berorientasi pada pembinaan nilainilai dengan cara menyentuh aspek emosi dan intuisi secara lebih intens.

b. Metode ibrah (perenungan), metode ini mengajak anak untuk mengembangkan nalar dan intuisinya dalam menemukan makna-makna esensial di belakang fakta-fakta empirik.

c. Metode hiwar (dialog), metode ini melibatkan anak secara dialogis dalam proses pembelajaran, sehingga pengetahuan dan makna atau nilai dapat dikontruksi secara bersama-sama antara pendidik dan terdidik.

d. Metode keteladanan yang baik, metode ini ditekankan agar nilai-nilai yang dibinakan kepada terdidik dapat terbaca secara konkret dari seluruh tindakan pendidik.

e. Metode amsal (perumpamaan), metode pendidikan ini membantu pemahaman terdidik dengan menggunakan perumpamaan yang konkret untuk memudahkan memahami sesuatu yang abstrak. ${ }^{9}$

Ayat 13 -19 Surah Luqman merupakan petunjuk bagaimana seorang ayah (ingat ayah bukan ibu) memberikan nasihat kepada anaknya:

\section{Pendidikan Aqidah (Ayat 13)}

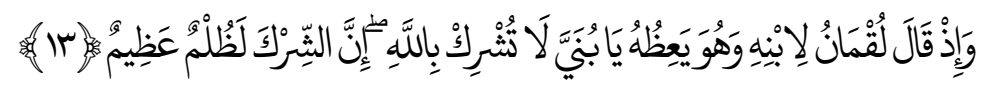

${ }^{9}$ Nashruddin Baidan, Metodologi Penafsiran al-Qur'an, (Yogyakarta: Pustaka Pelajar, 1998), h. 89. 
"Dan (ingatlah) ketika Luqman berkata kepada anaknya, di waktu ia memberi pelajaran kepadanya: "Hai anakku, janganlah kamu mempersekutukan Allah, Sesungguhnya mempersekutukan (Allah) adalah benar-benar kezaliman yang besar".

Kata yaidhuhu terambil dari kata wa'zh yaitu nasihat yang menyangkut berbagai kebijakan dengan cara yang menyentuh hati. Ada juga yang mengartikan sebagai ucapan yang mengandung peringatan dan ancaman. Penyebutan kata ini sesudah kalimat dia berkata untuk memberi gambaran tentang bagaimana perkataan itu beliau sampaikan, yakni tidak membentak tetapi penuh kasih sayang sebagaimana dipahami dari panggilan mesranya kepada anak. Kata ini juga mengisyaratkan bahwa nasihat itu dilakukannya dari saat ke saat sebagaimana dipahami dari bentuk kata kerja masa kini dan masa datang pada kata yaidhuhu. ${ }^{10}$

Luqman menasihati anaknya tidak menggunakan kata baniy yang artinya anakku, tetapi menggunakan kata bunayya yang berarti anak kecilku, merupakan isim tasghir dan di dalam kata tersebut penuh dengan rasa belas dan kasih orang tua terhadap anak agar tidak menyekutukan Allah karena menyekutukan Allah termasuk dosa yang besar.

Nasihat Luqman kepada anaknya merupakan nasihat tidak menggurui dan tidak mengandung tuduhan, karena orang tua tidak menginginkan kecuali kebaikan, dan orang tua hanya menjadi penasihat bagi anaknya. Luqman melarang anaknya dari perbuatan syirik, dia juga memberikan alasan atas larangan tersebut bahwa kemusyrikan itu adalah kedhaliman yang besar. Pernyataan Luqman tentang hakekat itu diperkuat dengan dua tekanan, yang pertama mengawalinya dengan larangan berbuat syirik dan alasannya yang kedua dengan menggunakan huruf inna yang berarti sesungguhnya dan huruf la yang bermakna benar-benar. ${ }^{11}$

Nasihat orang tua terhadap anaknya bebas dari segala syubhat dan jauh dari segala prasangka. Sesungguhnya perkara tauhid dan larangan berbuat syirik merupakan perkara lama yang selalu diserukan oleh orangorang yang dianugerahkan hikmah oleh Allah diantara manusia.

\footnotetext{
${ }^{10}$ M. Quraish Shihab, Tafsir al-Misbah, h. 298.

${ }^{11}$ Sayyid Quthb, Tafsir Fi Zhilalil-Qur'an: Di Bawah Naungan al-Qur'an, Jilid 9, Jakarta: Gema Insani Press, 2004), h. 173.
} 
Dalam hal keagamaan, ada beberapa aspek yang sangat penting untuk diperhatikan orang tua, yaitu pendidikan ibadah, pendidikan pokok-pokok ajaran agama, pendidikan akhlakul karimah dan pendidikan aqidah islamiyah.

Diantara karakter dasar anak adalah potensi kebaikan (keagamaan). Potensi ini tentu bersumber pada ajaran agama, ujung-ujungnya adalah sebuah sikap untuk mengenal dan mengesakan Tuhan. Dengan mengajarkan beragama yang baik, secara tidak langsung memerintahkan anak untuk berbuat kebajikan. Banyak cara yang dapat dilakukan dalam mengaplikasikan pendidikan ini. Orang tua dapat mengajarkan anak tentang mengenal Tuhan secara perlahan dari segala sesuatu yang kongkret (nyata), misalnya Tuhan itu Penyayang, Tuhan itu Pengasih dan lain-lain. Tuhan itu maha Kuasa terhadap segala alam, ingat seorang anak. Menurut al-Qur'an manusia (termasuk anak) adalah makhluk spiritual. Dia punya peranan yang penting dipanggung kehidupan dunia ini dan aktifitasnya diatur oleh prinsip dasar tertentu yang dilanggar akan menjadi orang jahat dan jika dipatuhi akan menjadi orang baik. Dari keadaan yang demikian, manusia sering disebut sebagai homo religius. Dengan ada fitrah beragama, manusia memerlukan pemenuhan kebutuhan rasa agama. ${ }^{12}$

Manusia yang sudah menempati posisi mengenal Tuhanya akan meresapi kekuasaanNya sebagaimana janji primordial yang pernah manusia ucapkan dalam Surah al-A'raf ayat 172. Status yang sudah sesuai dengan kehendak Allah inilah yang dinamakan dengan status fitrah. Ini artinya manusia lahir dengan ilmu dan pengetahuan tentang kondisi ideal.

Untuk dapat mewujudkan pendidikan ketauhidan dapat dilakukan sejak lahir. Misalnya ketika lahir diadzani, memberikan nama yang baik, melaksanakan aqiqah, mengajarkan ibadah dan memberikan pendidikan sesuai dengan tingkat usianya.

Anak harus diajarkan untuk meminta pertolongan hanya kepada Allah, bukan yang lain, bahkan harus diajarkan tentang al-Qur'an sebagai pedoman. Orang tua juga harus memperkenalkan sifat-sifat Allah yang Maha Pemurah, Maha Penyayang dan seterusnya. Dengan mulai mengenalkan Allah sedikit demi sedikit maka anak akan mulai bisa mengenal

${ }^{12}$ Muh. Anis, Sukses Mendidik Anak Perspektif al-Qur'an dan Hadis, (Yogyakarta: Pustaka Insan Madani, 2009), h. 170. 
siapa Tuhannya, Kebesaran dan Kekuasaannya yang tentu saja dengan tata cara yang lembut.

Kalimat indah yang disampaikan orang tua kepada anak yang masih kecil akan berbengaruh pada psikologi anak, dia kan ingat terus dengan kebiasaan orang tua yang berkata lembut dan ada kemungkinan akan terulang ketika anak tersebut menjadi orang tua. Dalam pertumbuhan jasmani dan perkembangan rohani anak akan terikat pada kematangan anak.

\section{Berbakti kepada Orang Tua (Ayat 14)}

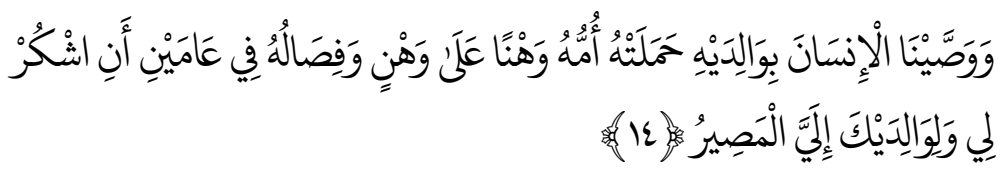

"Dan Kami perintahkan kepada manusia (berbuat baik) kepada dua orang ibu- bapanya; ibunya telah mengandungnya dalam Keadaan lemah yang bertambah-tambah, dan menyapihnya dalam dua tahun. bersyukurlah kepadaku dan kepada dua orang ibu bapakmu, hanya kepada-Kulah kembalimu."

Ayat di atas mengingatkan seorang anak agar mengingat betapa seorang orang tuanya terutama ibu yang mengandung dengan susah payah, mulai dari mengandung sampai melahirkan dan menyapih sampai usia dua tahun.

Ada beberapa ayat al-Qur'an yang berisi wasiat berbakti kepada orang tua, seperti ayat 8 Surah al-Ankabut, dan ayat 15 Surah al-Ahqaf. Namun ada perbedaan yang disebabkan kontek Surah Luqman ini adalah uraian tentang wasiat Allah bagi umat terdahulu, sedangkan Surah al-Ankabut dan al-Ahqaf merupakan tuntunan bagi umat Muhammad. Dalam kontek ini Ibnu Asyur mengemukakan riwayat bahwa Luqman ketika menyampaikan nasihat ini kepada anaknya, dia menyampaikan juga bahwa: "Sesugguhnya Allah telah menjadikan aku rela kepadamu sehingga Dia tidak mewasiatkan aku terhadapmu, tetapi Dia belum menjadikan engkau rela kepadaku maka Dia mewasiatkanmu berbakti kepadaku." 13

Ayat di atas tidak menyebutkan jasa bapak tetapi menyebutkan jasa Ibu. Ini karena ibu berpotensi untuk tidak dihiraukan oleh anak karena

${ }^{13}$ M. Quraish Shihab, Tafsir al-Misbah, h. 300. 
kelemahan ibu dan dalam kontek melahirkan peranan bapak lebih ringan dibanding ibu.

Nasihat di atas bisa bermakna untuk anak agar mengingat jerih payah orang tua sekaligus mengingatkan orang tua bahwa ada kewajiban bagi orang tua untuk menjaga bayi meskipun masih di dalam kandungan. Orang tua harus memberikan harta yang halal agar agar anak lahir degan badan yang kuat dan jiwa dan akal yang sehat. Jangan sampai ada makanan yang syubhat atau haram yang dikonsumsi oleh keluarga karena hadis sudah jelas mengatakan bahwa yang haram itu jelas dan yang haram juga sudah jelas keterangannya.

Peranan ibu dalam keluarga sangat penting. Dialah yang mengatur, membuat rumah tangganya menjadi surga bagi anggota keluarganya dan menjadi mitra sejajar yang saling menyayangi dengan suaminya. Untuk itu sebagai seorang ibu menyususi adalah kewajiban utama dalam memenuhi kebutuhan jasmani anak pada waktu bayi.

Selama dua tahun ibu menyususi anak nya dengan ASI. ASI atau air susu ibu merupakan emulsi lemak dalam larutan protein, laktosa, dan garam-garam anorganik yang disekresi oleh kelenjar mamae ibu, yang berguna sebagai makanan bayi. ASI merupakan cairan putih yang dihasilkan oleh kelenjar payudara ibu melalui proses menyusui. ${ }^{14}$ Adapun kandungan ASI adalah:

a. Kolostrum, adalah air susu yang pertama kali keluar, yang disekresi oleh kelenjar payudara pada hari pertama sampai hari ke empat pasca persalinan. Kolostrum merupakan cairan dengan viskositas kental, lengket, dan berwarna kekuningan yang mengandung rendah lemak dan laktosa. Di dalam kolostrum banyak mengandung protein, mineral, garam, vitamin A, nitrogen, sel darah putih dan antibodi yang tinggi dari pada ASI matur. Kolostrum juga merupakan pencahar ideal untuk membersihkan zat yang tidak terpakai dari usus bayi yang baru lahir dan mempersiapkan saluran pencernaan makanan bagi bayi yang akan datang.

b. Air susu transisi/peralihan yaitu ASI yang keluar setelah kolostrum sampai sebelum ASI matang, yaitu sejak hari ke-4 sampai hari ke-10.

${ }^{14}$ Siti Nur Khamzah, Segudang Keajaiban ASI yang Harus Anda Ketahui, (Yogyakarta: FlashBooks, 2012), h. 37-38. 
Selama dua minggu, volume air susu bertambah banyak dan berubah warna serta komposisinya. Kadar imunoglobulin dan protein menurun, sedangkan lemak dan laktosa meningkat.

c. Air susu matur yaitu ASI matur berwarna putih, yang disekresi pada hari ke sepuluh dan seterusnya. Kandungan ASI matur relatif konstan, tidak menggumpal bila dipanaskan. Air susu yang mengalir pertama kali atau saat lima menit pertama disebut foremilk, yang rendah lemak dan tinggi laktosa, gula, protein, mineral dan air. Selanjutnya, air susu berubah menjadi hindmilk, yang kaya akan lemak dan nutrisi.

Berikut perbedaan komposisi antara kolostrum, ASI transisi, dan ASI matur.

Perbedaan Komposisi antara

Kolostrum, ASI Transisi, dan ASI Matur ${ }^{15}$

\begin{tabular}{|l|c|c|c|}
\hline \multicolumn{1}{|c|}{ Kandungan } & Kolustrum & Transisi & ASI Matur \\
\hline Energi (kgkal) & 57,0 & 63,0 & 65,0 \\
\hline Laktosa (gr/100 ml) & 6,5 & 6,7 & 7,0 \\
\hline Lemak (gr/100 ml) & 2,9 & 3,6 & 3,8 \\
\hline Protein (gr/100 ml) & 1,195 & 0,965 & 1,324 \\
\hline Mineral (gr/100 ml) & 0,3 & 0,3 & 0,2 \\
\hline Immunoglubin: & & & \\
\hline Ig A (mg/100 ml) & 335,9 & - & 119,6 \\
\hline $\operatorname{lg~G~(mg/100~ml)~}$ & 5,9 & - & 2,9 \\
\hline Ig M (mg/100 ml) & 17,1 & - & 2,9 \\
\hline Lisosin (mg/100 ml) & $14,2-16,4$ & - & $24,3-27,5$ \\
\hline Laktoferin & $420-520$ & - & $250-270$ \\
\hline
\end{tabular}

Melihat pentingnya kandungan ASI bagi perkembangan anak, maka perlu diingat bagi para ibu betapa kasih sayang yang diberikan melalui kasih sayang ASI akan membangun karakter yang baik bagi anak. h. $166-168$.

${ }^{15}$ Dewi Maritalia, Sujono Riyadi, Biologi Reproduksi, (Yogyakarta: Pustaka Pelajar, 2011), 
Mengasuh anak memerlukan sikap sabar dan tutur kata yang baik atau qaulan karima. Tanpa qaulan karima ucapan yang keluar terhadap anak hanya hardikan dan cacian yang membuat anak merasa tidak disukai meskipun bagi orang tua hardikan itu untuk kebagikan anak. Maka ketika orang tua memperlakukan anak dengan baik maka orang tua akan memperoleh balasan wa bilwalidaini ihsana. Dalam penafsiran penggalan ayat tersebut, anak dituntut berbuat baik kepada kedua orang tua disebabkan orang tua telah berbuat ihsan kepada anak; mengandung selama sembilan bulan, melahirkan, mengasuh, merawat hingga anak tumbuh dewasa. Dengan demikian, perintah anak untuk berbuat ihsan kepada orang tua menjadi wajib dengan syarat orang tua telah terlebih dahulu berbuat ihsan kepadanya. Ihsan orang tua terhadap anak sangat urgen sebab seorang anak yang dilahirkan ke dunia ini dalam keadaan lemah tanpa daya dan membutuhkan pertolongan orang lain.

\section{Larangan Taat Kepada Orang Tua dalam Hal Kemusyrikan (Ayat 15)}

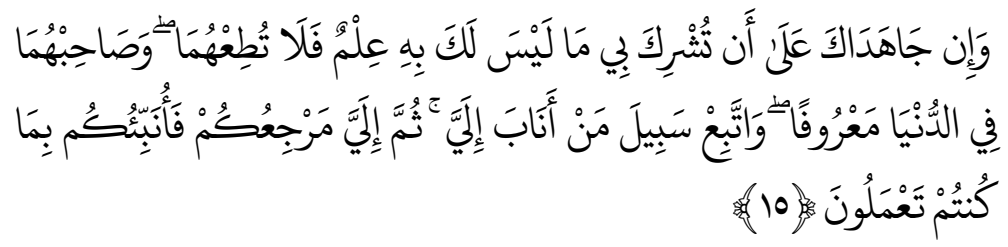

"Dan jika keduanya memaksamu untuk mempersekutukan dengan aku sesuatu yang tidak ada pengetahuanmu tentang itu, Maka janganlah kamu mengikuti keduanya, dan pergaulilah keduanya di dunia dengan baik, dan ikutilah jalan orang yang kembali kepada-Ku, kemudian hanya kepada-Kulah kembalimu, Maka Kuberitakan kepadamu apa yang telah kamu kerjakan."

Jika orang tua menyuruh untuk berbuat syirik jangan pernah ditaati meskipun harus tetap bermuamalah dengan makruf di dunia. Ini artinya meskipun orang tua sebagai orang yang berjasa terhadap anaknya, tapi tetap saja orang tua adalah manusia biasa yang ada kekurangannya, sehingga tidak menutup kemungkinan jika orang tua tidak sefaham atau seiman dengan anaknya. Namun dengan kebijakan Allah maka ikatan tauhid tetap di nomer satukan, artinya Allahlah yang harus diutamankan bukan ikatan 
darah antara anak dan orang tua jika berkaitan dengan perintah orang tua yang menghendaki kemusyrikan.

Dalam nasihat ayah kepada anaknya al-Qur'an memaparkan hubungan antara kedua orang tua dengan anak-anak mereka dalam tata bahasa yang detil dan teliti. Allah menggambarkan hubungan ini dalam gambaran yang mengisaratkan kasih sayang dan kelembutan. Walaupun demikian sesungguhnya ikatan akidah harus dikedepankan dari hubungan darah yang kuat. ${ }^{16}$

Banyak orang tua yang sefaham dan seiman dengan anak tetapi tidak sebagai orang tua yang taat terhadap aturan agamanya. Seringkali bisa dilihat orang tua mengantarkan anaknya ke sekolah, anak memakai seragam berjilbab sementara ibunya hanya memakai pakaian seadanya tanpa memakai hijab. Maka yang timbul dalam hubungan keluarga adalah tidak ada rasa kepercayaan anak terhadap agama yang dianutnya karena tidak ada figur dan contoh dari keluarga. Pada akhirnya anak juga akan berbuat sama dengan apa yang telah dilakukan orang tua terhadap anaknya. Maka menjadi wajib bagi orang tua harus untuk terlebih dahulu berbuat sesuatu yang mencerminkan ajaran agama kepada anaknya.

\section{Keimanan (Ayat 16)}

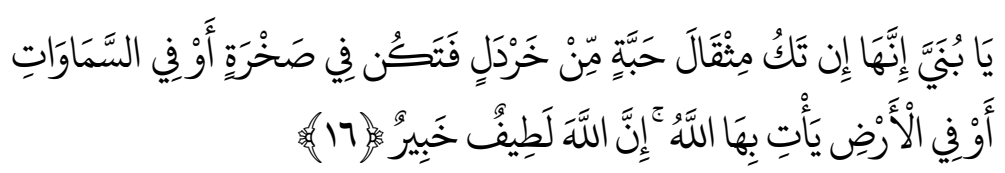

"(Luqman berkata): "Hai anakku, Sesungguhnya jika ada (sesuatu perbuatan) seberat biji sawi, dan berada dalam batu atau di langit atau di dalam bumi, niscaya Allah akan mendatangkannya (membalasinya). Sesungguhnya Allah Maha Halus lagi Maha mengetahui."

Wasiat Luqman selanjutnya adalah bahwa apapun yang diperbuat oleh manusia entah sebesar biji sawi, kecil, tertimbun di kedalaman bumi atau tingginya langit maka akan dibalas oleh Allah. ${ }^{17}$

Ketika memaknai kata Khardal pada Surah al-Anbiya ayat 47, Quraisy Shihab menukil pendapat dari tafsir al-Muntakhab yang melukiskan biji

${ }^{16}$ Sayyid Quthb, Tafsir Fi Zhilalil-Qur'an: Di Bawah Naungan al-Qur'an, Jilid 9, h. 174.

${ }^{17}$ al-Malikiy, Hasyiyah al-Allamah Shawiy ala Tafsir al-Jalalain, h. 316. 
tersebut. Disana dinyatakan bahwa satu kg biji khardal terdiri atas 913.000 butir. Dengan demikian berat satu butir biji hanya 1/1000 gram dan merupakan biji-bijian teringan yang diketahui umat manusia sampai sekarang. ${ }^{18}$

Ayat di atas mengisyaratkan kepada anak agar anak yakin bahwa apapun yang pernah dilakukan manusia maka akan dihitung. Dal hal ini orang tua juga harus mengajarkan kepercayaan atau keimanan terhadap Allah kepada anak. Dengan demikian anak tidak berani berbohong di belakang orang tua karena yakin bahwa Allah tahu apapun yang terlihat jelas atau yang tersembunyi sehingga amalan sebesar khardal saja akan dibalas oleh Allah.

Orang tua harus mengajarkan konsep pahala dan dosa kepada anak supaya dia dapat memahami bahwa semua perbuatannya akan dipertanggungjawabkan di hadapan Allah.

Setiap anak pasti mempunyai sesuatu karya yang patut untuk dihargai, sekecil apapun bentuk karya yang dihasilkan tersebut selayaknya diberikan pujian atau penghargaan ynag maksimal. Tanpa disadari pujian ini menjadi motivasi dan semangat bagi anak-anak untuk terus belajar dan terus berkarya. Jika tidak menghargai bahkan sampai diejek maka hanya membuat jatuh harga diri anak dan membuat anak trauma serta malas melakukan lagi. Menghargai apapun yang dikerjakan oleh anak, sekecil apapun akan membuat anak menjadi merasa diapresiasi kemampuannya. Menghargai prestasi, akan mendorong dirinya untuk menghasilkan sesuatu yang berguna bagi masyarakat, dan mengakui serta menghargai keberhasilan orang lain.

\section{Pendidikan Ibadah (Ayat 17)}

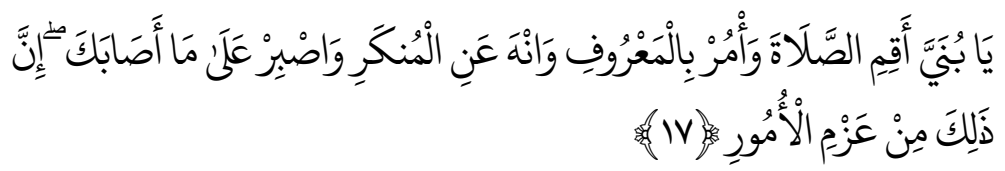

"Hai anakku, dirikanlah shalat dan suruhlah (manusia) mengerjakan yang baik dan cegahlah (mereka) dari perbuatan yang mungkar dan bersabarlah terhadap apa yang menimpa kamu. Sesungguhnya yang demikian itu Termasuk hal-hal yang diwajibkan (oleh Allah)."

${ }^{18}$ Quraish Shihab, Tafsir al-Misbah: Pesan, Kesan dan Keserasian al-Qur'an, Vol. 10., h. 306. 
Luqman berwasiat agar anaknya mendirikan shalat dan melakukan amar makruf dan menolak kemungkaran serta bersabar atas segala musibah yang menimpa, karena itu merupakan bagian yang diwajibkan oleh Allah.

Perintah melaksanakan shalat ada dua pengertian dalam ayat ini pertama, shalat yang mafhum di masa zaman Arab yaitu masalah ketuhanan, doa, merayu Tuhan, memuji dan mengagungkan-Nya, sebagaimana firman Allah dalam Surah al-Ahzab ayat 56. Ayat dalam Surah Luqman di atas aqimis shalah menunjukan makna doa, istighfar, rahmah dan maghfirah. Kedua shalat yang dipahami sebagai sesuatu yang dan disyari'atkan. ${ }^{19}$

Sikap relgius ini dapat ditanamkan kepada anak usia dini dengan memberikan berbagai kegiatan keagamaan untuk anak. Misalnya mengajarkan anak shalat secara bersama-sama, melatih anak berdoa sebelum makan dan sebelum tidur. Jika ditanamkan terus menerus maka nilai religiusitas pada anak akan tertanam.

Luqman meneruskan dengan beban aqidah dengan perintah amar makruf dan nahi munkar dan bersabar atas segala konsekuensinya. Segalanya adalah resiko dari pemegang akidah ketika melangkah dengan langkah-langkah yang merupakan tabiat dari akidah tersebut. ${ }^{20}$

Bersamaan dengan amar makruf nahi munkar, bersabar akan segala konsekuensinya dan resiko yang harus dihadapi dan menimpa diri, maka seorang pendakwah harus beradab dengan adab seorang pendakwah yang menyeru kepada Allah, yaitu agar tidak sombong kepada manusia sehingga dengan perilaku tersebut dia merusak perkataan baik yang telah diserukan dengan contoh buruk yang dilakukannya. ${ }^{21}$

Motivasi yang bisa diberikan kepada anak adalah orang tua menjadi teladan didepan anaknya. Dengan memberikan teladan yang baik maka sama saja sedang beramar makruf dalam bentuk mendirikan bangunan moral, spiritual dan etos sosial kepada anak. Seorang anak akan tumbuh menjadi pribadi yang jujur, berakhlaq mulia, berani menghadapi tantangan dan konsisten. h. 306.

${ }^{19}$ al-Maturidy, Takwilaat Ahli Sunah Tafsir al-Maturidi, (Bairut: Dar a-Kutub, 2005), Jilid 8,

${ }^{20}$ Sayyid Quthb, Tafsir Fi Zhilalil-Qur'an: Di Bawah Naungan al-Qur'an, Jilid 9, h. 164.

${ }^{21}$ Ibid., h. 165. 


\section{Pendidikan Akhlaq (Ayat 18-19)}

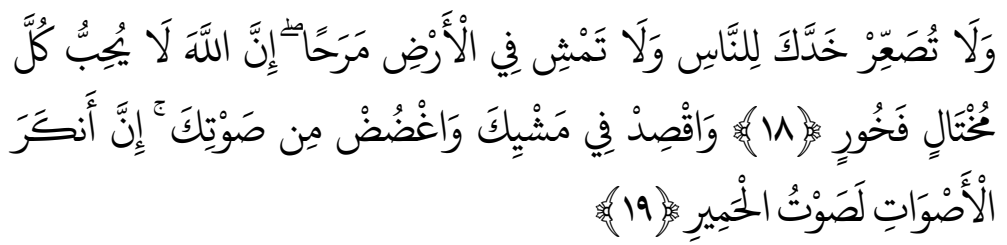

"Dan janganlah kamu memalingkan mukamu dari manusia (karena sombong) dan janganlah kamu berjalan di muka bumi dengan angkuh. Sesungguhnya Allah tidak menyukai orang-orang yang sombong lagi membanggakan diri. Dan sederhanalah kamu dalam berjalan dan lunakkanlah suaramu. Sesungguhnya seburuk-buruk suara ialah suara keledai."

Nasihat Luqman kali ini berhubungan dengan akhlaq, sopan santun berinteraksi dengan sesama manusia. Materi pelajaran aqidah beliau selingi dengan materi pelajaran akhlaq. Bukan saja agar anak tidak jenuh dengan satu materi tetapi juga untuk mengisaratkan bahwa ajaran aqidah dan akhlaq merupakan satu kesatuan yang tidak dapat dipisahkan. Beliau menasihati anaknya dengan berkata: "dan wahai anakku, janganlah engkau berkeras memalingkan pipimu, yakni mukamu dari manusia siapapun dia didorong oleh penghinaan dan kesombongan. Tapi tampilah pada setiap orang dengan wajah berseri dengan penuh rendah hati. Dan bila engkau melangkah janganlah berjalan dimuka bumi dengan dengan angkuh tetapi berjalanlah dengan lemah lembut penuh wibawa. Sesungguhnya Allah tidak menyukai yakni tidak melimpahkan anugerah kasih sayang-Nya kepada orang-orang yang sombong lagi membanggakan diri. Dan bersikap sederhanalah dalam berjalanmu yakni jangan membusungkan dada dan jagan pula merunduk bagaikan orang sakit. Jangan berlari tergesa-gesa dan jangan juga dengan berlahan menghabiskan waktu. Dan lunakkan suaramu sehingga tidak terdengar kasar bagaikan teriakan keledai. Sesungguhnya seburuk-buruk suara adalah keledai karena awalnya siulan yang tidak menarik dan akhirnya tarikan nafas yang buruk. ${ }^{22}$

Kata fil ardh disebut oleh ayat di atas untuk mengisyaratkan bahwa asal kejadian manusia dari tanah sehingga dia hendaknya jangan menyombong-

${ }^{22}$ Quraish Shihab, Tafsir al-Misbah: Pesan, Kesan dan Keserasian al-Qur'an, Vol. 10, h. 312. 
kan diri dan melangkah angkuh ditempat itu, demikian kesan dari al-Biqa'i. Ibnu Atsur memeroleh kesan bahwa bumi adalah tempat berjalan semua orang yang kuat dan yang lemah yang kaya dan yang miskin, penguasa dan rakyat jelata. Mereka semua sama sehingga tidak wajar bagi pejalan yang sama menyombongkan diri dan merasa melebihi yang lain. ${ }^{23}$

Nilai pokok yang disampaikan kepada anak adalah cinta damai. Cinta damai adalah sikap, perkataan dan tindakan yang menyebabkan orang lain merasa senang atas kehadiran dirinya. Cinta damai merupakan sikap yang patut untuk dilestarikan kepada anak-anak. Sejak kecil sikap cinta damai sudah harus dipupuk. Praktiknya dengan melatih anak untuk meinta maaf atau memaafkan, memohon ijin bila melakukan sesuatu yang melibatkan hak orang lain dan minta tolong bila membutuhkan bantuan orang lain.

Kata mukhtalan terambil dari akar kata khayaal. Karenanya kata ini pada mulanya berarati orang yang bertingkah lakunya diarahkan oleh hayalannya, bukan oleh kenyataan yang ada pada dirinya. Biasanya orang seperti ini berjalan angkuh dan merasa dirinya memiliki kelebihan dibandingkan dengan orang lain. Dengan demikian keangkuhannya tampak secara nyata dalam kesehariannya. Kuda dinamakan khail karena cara jalannya yang mengesankan keangkuhan. Seseorang yang mukhtal membanggakan apa yang dimilikinya bahkan tidak jarang membanggakan apa yang pada hakekatnya tidak dia miliki. Inilah yang ditunjukkan oleh kata fakhura yakni seringkali membanggakan diri. Memang kedua kata ini mengandung makna kesombongan. Kata yang pertama mengandung makna kesombongan yang terlihat dalam tingkah laku. Sedangkan yang kedua adalah kesombongan yang terdengar dari ucapan-ucapan. Disisi lain perlu dicatat bahwa penggabungan dari kedua hal itu bukan berarti ketidak senangan Allah baru lahir bila keduanya tergabung bersama-sama dalam diri seseorang. Jika salah satu sifat itu disandang manusia, hal ini telah mengundang murka-Nya. Penggabungan keduanya pada ayat ini atau ayat lainya hanya bermaksud menggambarkan bahwa salah satu dari keduanya seringkali berbarengan dengan yang lain. ${ }^{24}$

Bersahabat atau komunikatif merupakan tindakan yang melibatkan rasa senang berbicara, bergaul dan bekerja sama dengan orang lain. Per-

\footnotetext{
${ }^{23} \mathrm{Ibid}$.

${ }^{24}$ Ibid.
} 
sahabatan dan komunikasi sangat erat kaitannya. Untuk dapat bersahabat dengan baik dibutuhkan komunikasi yang baik pula. Seorang anak harus dibiasakan bersahabat dan berkomunikasi kepada anak-anak lain.

Melatih anak berkomunikasi akan membuat anak semakin tahu kebutuhan adanya teman, tidak merasa bisa mengerjakan pekerjaan sendiri tetapi lebih pada membutuhkan orang lain.

Kata ughdhudh terambil dari kata ghadh dalam arti penggunaan sesuatu tidak dalam potensinya yang sempurna, maka dapat memandang ke kiri dan ke kanan secara bebas. Perintah ghadh jika ditujukan kepada mata, kemampuan itu hendaklah dibatasi dan tidak digunakan secara maksimal. Demikian juga suara. Dengan perintah di atas, seseorang diminta untuk tidak berteriak dengan sekuat kemamapuannya tetapi dengan suara perlahan namun tidak harus berbisik. ${ }^{25}$

Sebagai orang tua, mulai sekarang harus berhati-hati dengan anak. Hindari kata-kata negatif, seperti membentak, terlalu menyalahkan terlebih memaki. Menurut praktisi emotional intellegent parenting, Hanny Muchtar Darta, sering berkata negatif pada anak dapat membuat konsentrasi dan daya ingat mereka melemah. Hasil penelitian di Amerika yang dilakukan Taks Force for Personal and Social Responsibilities juga menyebutkan bahwa anak yang setia hari mendengar 432 kata negatif dan hanya mendengar 32 kata atau kalimat positif maka sebanyak 80\% dari akat-kata tersebut berdampak negatif pada perkembangan spsikologinya. Karena itu butuh komuniasi secara positif dengan anak-anak agar mereka tumbuh cerdas san genius. ${ }^{26}$

Wujud memperhatikan psikologis anak bisa ditampilkan dalam bentuk sikap dan perkataan. Allah mewajibkan anak untuk berkata lemah lembut dan tidak menghardik orang tua ketika mereka telah pikun karena orang tua telah berlaku sabar dalam mendidik, bersikap lembut dan tidak menghardik anak ketika masih kecil. Balasan terhadap orang tua ini bukan tanpa tuntutan tetapi orang tua harus lemah lembut dalam perkataan dan tidak menghardik anak. Anak kecil yang belum bisa berpikir rasional dan logis sama

\footnotetext{
${ }^{25} \mathrm{Ibid}$.

${ }^{26}$ Salman Rusydie, Kebiasaan-kebiasaan Khusus Pembuat Daya Ingat Anak Semakin Cemerlang, (Jogjakarta: Laksana, 2012), h. 100-101.
} 
halnya seperti orang tua yang telah pikun. Anak kecil tentunya akan merasa senang dengan dunianya demikian juga dengan orang tua yang telah pikun.

Penghinaan dan celaan adalah tindakan yang dilarang dalam pendidikan, sekalipun terhadap bocah kecil yang belum berumur satu bulan. Anak bayi sangatlah peka perasaannya. Ia dapat merasakan orang tua tidak senang dan tidak menyukainya melalui sikap, bahkan yang masih tersirat dalam hati orang tua, lebih-lebih lagi melalui perkataan yang jelas. Dengan memberikan teladan yang baik, maka sebenarnya orang tua sedang mempersiapkan bangunan moral, spiritual dan etos sosial kepada anak.

\section{E. Kesimpulan}

Luqman Hakim menyampaikan nasihat yang mencakup pokok-pokok tuntunan agama. Adapun kesimpulan pelajaran yang diperoleh pada ayatayat di atas adalah: 1) Tuntunan aqidah agar mengesakan Allah. 2) Tuntunan syariah menjalankan shalat, amar makruf nahi mungkar dan bersabar dengan segala kesusahan yang menimpa. 3) Tuntunan akhlaq kepada anak dalam bermasyarakat.

Ketiganya merupakan unsur yang ada dalam al-Qur'an di dalamnya ada akhlaq kepada Allah, akhlaq kepada orang lain dan terhadap diri sendiri. Ada perintah moderasi yang merupakan ciri dari segala macam kebijakan serta perintah bersabar yang merupakan sarat mutlak meraih sukses, duniawi dan ukhrawi.

Metode keteladanan adalah metode influitif yang meyakinkan keberhasilannya dalam mempersiapkan moral spiritual dan sosial anak, sebab pendidikan adalah contoh terbaik dalam pandangan anak yang akan ditiru dalam tindak tanduk dan sopan santunnya terpatri dalam jiwa.

Keteladanan merupakan unsur paling mutlak untuk melakukan perubahan perilaku hidup. Seorang anak bahkan orang dewasa secara psikologis memiliki kemampuan untuk menyerap informasi dan pengaruh dari luar dengan kalkulasi-kalkulasi, pengaruh yang diserap melalui mata sebanyak $84 \%$, melalui telinga $11 \%$, sesangkan lainnya adalah fakta lain. Melalui mata atau keteladanan artinya apa yang dilihat dan disaksikan akan dicontoh, melalui nasihat, tausiyah, saran, pendapat hanya efektif mengubah perilaku sebanyak $11 \%$. Artinya nasihat yang tidak dibarengi keteladanan sama dengan membawa garam ke laut untuk mengasinkan laut, sebauah perbuatan yang lebih banyak sia-sianya daripada manfaatnya, 
inipun salah satu implikasi mengapa ada ayat khusus menyuruh kita meneladani Nabi Muhammad. ${ }^{27}$

Berkaitan dengan hal ini, orang tua tidak mengabaikan aspek psikologis dalam mengasuh anak mengingat anak memerlukan perhatian dan kasih sayang. Sebagai anak yang belum bisa berpikir logis, anak tetap memerlukan kasih sayang dan cinta orang tua. Kasih sayang tidak sama dengan pelimpahan materi. Pemberian materi yang banyak tanpa perhatian dan rasa cinta dari orang tua akan membuat anak merasa tidak ada ikatan emosi antara dirinya dan orang tua. Akibatnya anak tidak peka terhadap apa yang dirasakan oleh orang tuanya, apalagi ketika orang tua telah renta.

Memerlakukan anak dengan lemah lembut dan penuh kasih sayang bukan hanya membantu anak berkembang dengan positif tetapi juga memudahkan orang tua untuk mengontrolnya. Di saat orang tua bersikap lemah lembut dan sayang kepadanya, maka anak tersebut akan mudah untuk diajak kerja sama dan akan bersikap menurut.[]

\section{Daftar Pustaka}

Ahsin Sakho Muhammad, et. al., Al-Qur'an dan Tafirmya, Jakarta: Lentera Abadi, 2010.

Anis, Muh., Sukses Mendidik Anak Perspektif al-Qur'an dan Hadis, Yogyakarta: Pustaka Insan Madani, 2009.

Baidan, Nashruddin, Metodologi Penafsiran al-Qur'an, Yogyakarta: Pustaka Pelajar, 1998.

Burhanudin, Paradigma Psikologi Islam, Studi tentang Elemen Psikologi dari al-Qur'an, Yogyakarta: Pustaka Pelajar, 2004.

Khamzah, Siti Nur, Segudang Keajaiban ASI yang Harus Anda Ketahui, Yogyakarta: FlashBooks, 2012.

al-Malikiy, Hasyiyah al-Allamah Shawiy ala Tafsir al-Jalalain, Jilid 3, Beirut: Dar alFikr, 1993.

${ }^{27}$ Anwar Sanusi, Jalan Kebahagiaan, (Jakarta: Gema Insani Press, 2006), h. 225. 
Mansur, Pendidikan Anak Usia Dini dalam Islam, Yogyakarta: Pustaka Pelajar, 2009.

Maritalia, Dewi., Sujono Riyadi, Biologi Reproduksi, Yogyakarta: Pustaka Pelajar, 2011.

al-Maturidy, Takwilaat Ahli Sunah Tafsir al-Maturidi, Jilid 8, Beirut: Dar a-Kutub, 2005.

Quthb, Sayyid, Tafsir Fi Zhilalil-Qur'an: Di Bawah Naungan al-Qur'an, Jilid 9, Jakarta: Gema Insani Press, 2004.

Rusydie, Salman, Kebiasaan-kebiasaan Khusus Pembuat Daya Ingat Anak Semakin Cemerlang, Jogjakarta: Laksana, 2012.

Shihab, M. Quraish, Tafsir al-Misbah: Pesan, kesan dan Keserasian al-Qur'an, Vol. 10, Jakarta: Lentera Hati, 2009.

Sanusi, Anwar, Jalan Kebahagiaan, Jakarta: Gema Insani Press, 2006.

Soedomo, A. Hadi, Pendidikan: Suatu Pengantar, Surakarta: UNS Press, 2008. 
